\title{
Expressive Writing Therapy through Online and Offline Media to Reduce Nomophobia Level during the Pandemic Covid- 19
}

\author{
Arinda Ayudya Putri Riyanto*, Laila Rahmania Adjani, Serly Hanan Safirah, Anisa Fitriani \\ Faculty of Psychology, Sultan Agung Islamic University \\ Jl. Raya Kaligawe Km. 4 Semarang, Indonesia \\ *Correspondence: arindaayudya0@gmail.com
}

\begin{abstract}
Everyone needs a smartphone during the pandemic, which makes people use online communication more. However, inappropriate and excessive use can cause problems, such as nomophobia. This study aimed to determine the effect of expressive writing therapy in reducing the level of nomophobia. The research method uses a quasi-experimental design with a pretest-posttest design with a control group. The sampling technique used was purposive sampling with 23 male and female subjects aged 19-21 years who had moderate to high levels of nomophobia - collecting data through observation, interviews, and the Nomophobia Questionnaire (NMP-Q). Expressive writing therapy was given to the experimental group for five sessions through online and offline media. Data analysis using a quantitative approach with the Mann-Whitney statistical test obtained a significance of $p$ $=0.0425(P<0.05)$, so it can be concluded that there is a significant difference in nomophobia scores between the control and experimental groups after being given expressive writing therapy. The results of the qualitative analysis showed that the subject experienced nomophobia due to unpleasant past experiences, parenting and environmental demands, loneliness, and work needs. The decrease in nomophobia scores was influenced by various new understandings gained after receiving expressive writing therapy.
\end{abstract}

Keywords: expressive writing therapy, nomophobia, anxiety, smartphone.

Received 20 October 202I/Accepted 28 February 2022 @Author all rights reserved

\section{Introduction}

Indonesia is ranked first with users of smartphones most in Southeast Asia. Based on the data from Good News in 2018, I50.4 million, or around 56.2\% of Indonesia's population, use smartphones. In 2019 , there was an increase to $63.3 \%$, or around 170.6 million people. Smartphones have various applications that can make it easier for individuals to find information and communicate supported by internet data (Syahputra \& Erwinda, 2020). A survey conducted by Rapid Value Solution revealed that there were 57.5 million users in Indonesia (Lelepary, Mappeboki, and Nurafriani 2020). 
Smartphones are a significant need for every individual (Syahputra \& Erwinda, 2020). Smartphones have a high ability to access information, social gatherings, and even emotional exchanges and are easy to carry anywhere. As a communication medium, smartphones can facilitate every individual to contact and be contacted at any time. In addition to the benefits, there are several problems if the smartphone is not used wisely. Previous research has shown that the habit of frequently checking smartphones can lead to addiction (Gonzalez, Meija, Sancho \& Calvet,2017) and disrupted sleep quality (Li, Lepp \& Barkley, 20I5). Inappropriate and excessive use can result in anxiety that interferes with daily life, such as difficulty in social interaction, health problems, especially eye health, and being unproductive (Deursen, Bolle, Hegner \& Kommers, 20I5). Significantly during the current Covid-19 pandemic, the use of smartphones in modern society among teenagers is increasing (Fahrudin \& Cahyaningtyas 2020).

Individuals who experience dependence will feel anxious when far away from their smartphone or often called nomophobia (No Mobile Phone Phobia) (Fadhilah, Hayati \& Bashori 2020; Muyana and Widyastuti 2017). Nomophobia is a problem that causes discomfort, anxiety, anxiety because it cannot be connected to a smartphone (Ramaita \& Vandelis 2019). The 2015 survey showed $66 \%$ of respondents could not live without a smartphone then the percentage of nomophobia increased by $77 \%$ in respondents aged 18-24 years (Sudarji, 2017).

People with nomophobia feel fear and anxiety when leaving the house without a smartphone. Previous research has shown that nomophobia can affect social, academic, work-life (Syahputra \& Erwinda 2020) and cause many psychological problems, such as stress, anger, aggressiveness, unstable emotions (Argumosa, Boada \& Vigil 2017), easily depressed, anxious (Darvishi, Noori \& Karimi 2019). Symptoms of physical anxiety that appear include physical, emotional, cognitive, and behavioral symptoms (Salmiyati \& Ervika 2020).

The solution to overcome these problems is by therapy that can reduce anxiety symptoms to slowly feel comfortable even though they are not close to smartphones. One therapy that can be used is expressive writing therapy. According to Pennebaker, expressive writing is a cathartic process 
because it tells experiences or feelings in the form of words, sentences, or paragraphs (Pragholapati, Muliani, \& Yulianti, 202I).

Previous research has shown that expressive writing effectively reduces anxiety (Rohmadani, 2017). Recent research has proven that expressive writing also effectively reduces anxiety in victims of bullying (Niman, Septiningsih, \& Tania, 2019). That effect happens because expressive writing therapy can lead to a new understanding of feelings, emotions, and problems faced (Niman, et al., 2019). In addition, another recent study also stated that expressive writing is a form of self-disclosure and expression to effectively reduce stress and anxiety levels (Safitri \& Dewi 2020). Compared to previous studies, expressive writing was used to reduce anxiety symptoms in victims of bullying, not nomophobia. Therefore, the current study examines whether expressive writing therapy can reduce anxiety in people with nomophobia.

\section{Method}

Design

This study used a quasi-experimental approach with a pretest-posttest design with a control group to determine the effect of a treatment in expressive writing therapy by comparing the experimental and control groups. Measurements were taken before and after the treatment and two weeks after the treatment ended to determine the consistency of the effect of the treatment.

Expressive writing therapy was carried out in 4 sessions with 60 minutes per meeting duration. Subjects were given five days to write online and offline sessions by implementing health protocols during the Covid-19 pandemic. This research was carried out in the city of Semarang, online (within the network) and offline (outside the network) by implementing health protocols during the Covid19 Pandemic.

\section{Participants}

The sampling technique used purposive sampling or the determination of subjects based on specific criteria, namely individuals who have a level of nomophobia in the moderate to high category. The 

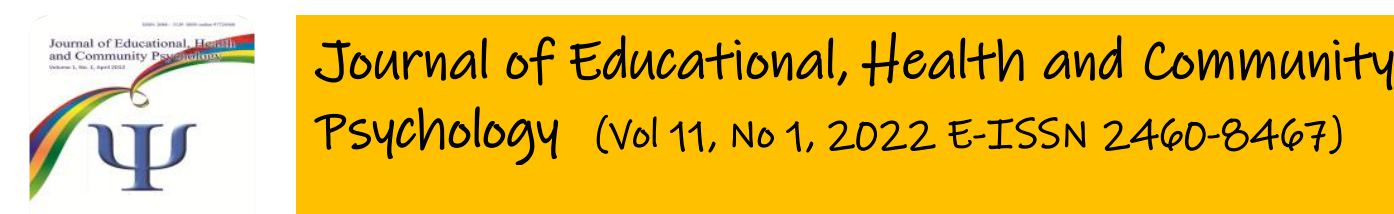

subjects in this study were 23 people in Semarang with an age range of 19-2I years and were divided into two groups, experimental and control. At the beginning of the study, respondents were given informed consent to participate in the entire research process.

\section{Measurements}

Observation, interviews, and measurement of scores nomophobia using the Nomophobia Questionnaire (NMP-Q) were used to collect the data. The NMP-Q consists of 20 items arranged based on nomophobia and has a Cronbach's Alpha reliability value of 0.93 (Yildirim, 20I4). From these calculations it can be concluded that the research questionnaire is considered reliable (Rangka 2018). The score is in the range of 20-140. The higher score, the higher the level of nomophobia.

\section{Data Analysis}

A quantitative approach through the Mann-Whitney test was used to determine the difference in the scores of nomophobia in the control and experimental groups. Qualitative data were analyzed with a descriptive narrative method to get a more in-depth description of the subject's condition before and after taking expressive writing therapy.

\section{Results}

The following data results show nomophobia following expressive writing therapy before and after (pretest and posttest). The subsequent measurement was carried out two weeks after the posttest to see the continued effect of expressive writing therapy on decreasing scores of nomophobia. 
Table I

Scores of pretest and posttest from the experimental group

\begin{tabular}{lllllllll}
\hline Subject & $\begin{array}{l}\text { Age } \\
\text { (years) }\end{array}$ & JK & Pretest & Category & Post-Test & Category & Follow Up & Category \\
\hline DN & 21 & L & 107 & High & 109 & High & 107 & High \\
SW & 19 & P & 109 & High & 68 & Medium & 56 & Mild \\
UL & 19 & P & 104 & High & 95 & Medium & 53 & Mild \\
KH & 19 & P & 110 & High & 95 & Medium & 100 & High \\
IT & 19 & P & 91 & Medium & 96 & Medium & 75 & Medium \\
SY & 20 & P & 89 & Medium & 66 & Medium & 89 & Moderate \\
NL & 20 & P & 91 & Moderate & 92 & Moderate & 74 & Moderate \\
AZ & 20 & P & 86 & Moderate & 72 & Moderate & 81 & Moderate \\
AG & 19 & L & 83 & Moderate & 66 & Moderate & 59 & Mild \\
SL & 19 & P & 90 & Moderate & 89 & Moderate & 95 & Moderate \\
YM & 19 & P & 89 & Moderate & 79 & Moderate & 85 & Moderate \\
\hline
\end{tabular}

Based on the data in table I, it can be seen that from the II subjects in the experimental group, eight subjects experienced a decrease in the NMP-Q score in the posttest measurement. Before testing the hypothesis, the researcher first tested for normality with the Kolmogorov Smirnov test and got the result that the data was not normally distributed, so the writer used the non-parametric statistical test Mann Withney. When compared with table I, table 2 shows the nomophobia score in the control group. That shows a decrease in scores in table 2 or the experimental group. 
Table 2

Scores of pretest and posttest from the control group

\begin{tabular}{lllllllll}
\hline Subject & $\begin{array}{l}\text { Age } \\
\text { (years) }\end{array}$ & JK & Pretest & Category & Post-Test & Category & Follow-up & Category \\
\hline FD & 19 & P & 140 & High & 122 & High & 56 & Mild \\
YE & 20 & L & 100 & High & 104 & High & 97 & Medium \\
NZ & 19 & P & 106 & High & 103 & High & 106 & High \\
WN & 19 & P & 107 & High & 106 & High & 106 & High \\
AD & 20 & P & 106 & High & 88 & Medium & 113 & High \\
JA & 21 & L & 119 & High & 112 & High & 118 & High \\
NS & 20 & P & 105 & High & 97 & Medium & 102 & High \\
GF & 19 & P & 95 & Medium & 92 & Medium & 98 & Medium \\
GB & 19 & L & 78 & Medium & 85 & Medium & 81 & Medium \\
IN & 19 & P & 83 & Medium & 82 & Medium & 78 & Medium \\
SF & 19 & P & 78 & Medium & 89 & Medium & 87 & Medium \\
OY & 20 & P & 97 & Medium & 83 & Medium & 81 & Moderate \\
\hline
\end{tabular}

The statistical test Mann Whitney on the NMP-Q scale scores in the experimental and control groups resulted in a $\mathrm{p}$-value $=0.0425(\mathrm{p}<0.05)$. After taking expressive writing therapy, there was a significant difference in scores between the experimental and control groups. Meanwhile, the $p$ value $=0.0395$ $(p<0.05)$ at follow-up, meaning a significant difference in scores between the experimental and control groups after two weeks of expressive writing therapy.

Changes in the score nomophobia of experimental group subjects between before and after treatment and follow-up can be seen from the graph below. 

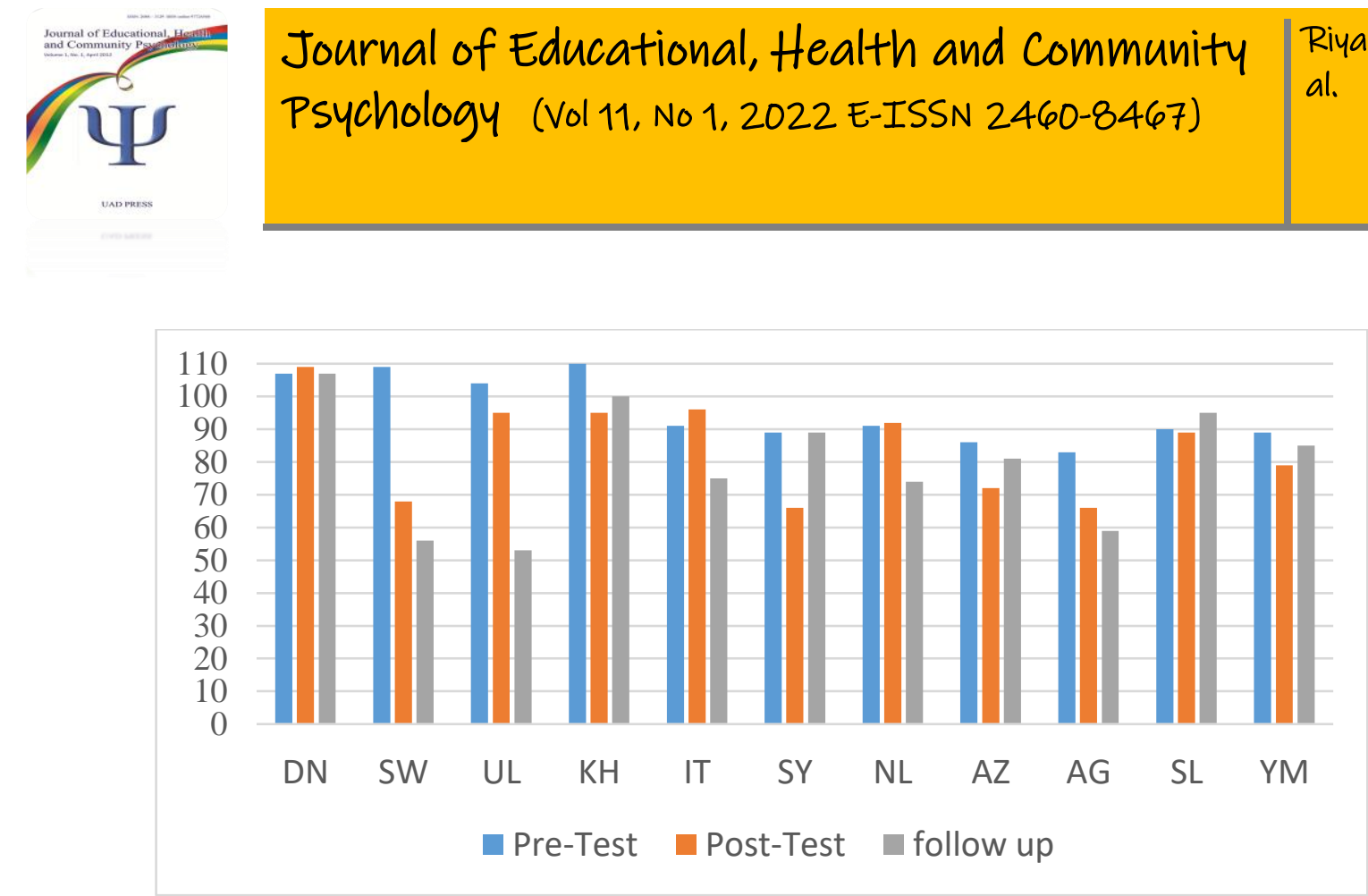

Graph I. The score of nomophobia in the experimental group

The average score at the time of measurements posttest and follow-up also decreased in the experimental group, from 95.373 at pretest to 84.273 at posttest and 79.454 at follow-up. At the same time, the control group went from 10I.167 at pretest to 96.917 at posttest and 93.583 at follow-up.

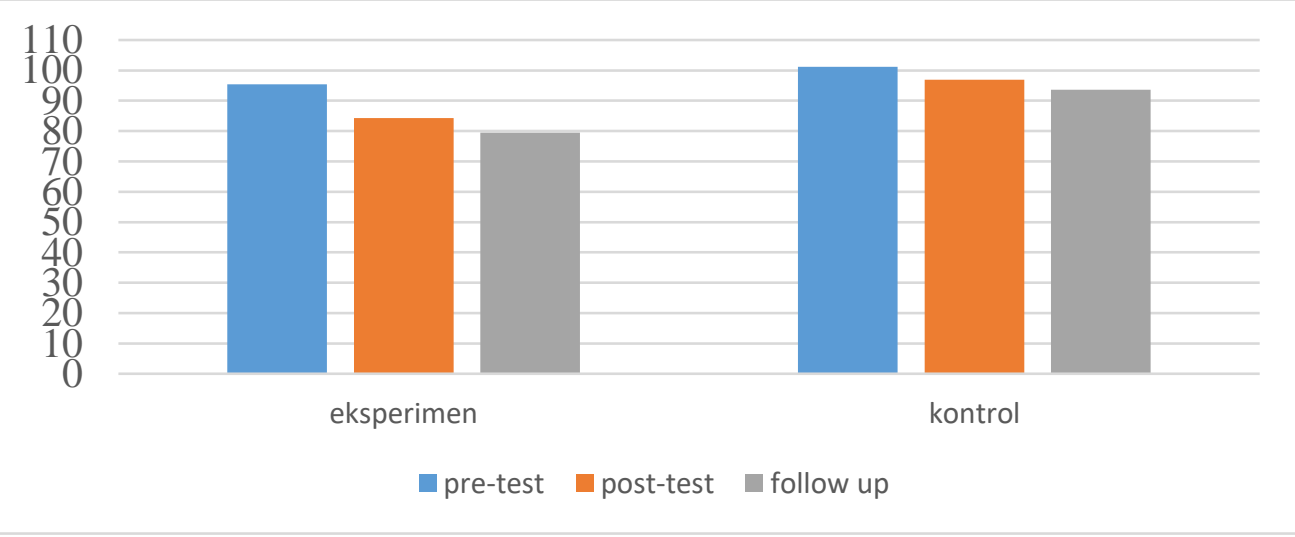

Graph 2. The difference in the average NMP-Q scores of the experimental and control groups.

Graph 2 above shows the difference in the average nomophobia scores in the experimental and control groups during pretest, posttest, and follow-up. Aspects of nomophobia which consist of anxiety about losing access to information, discomfort, anxiety about losing access to communication, 

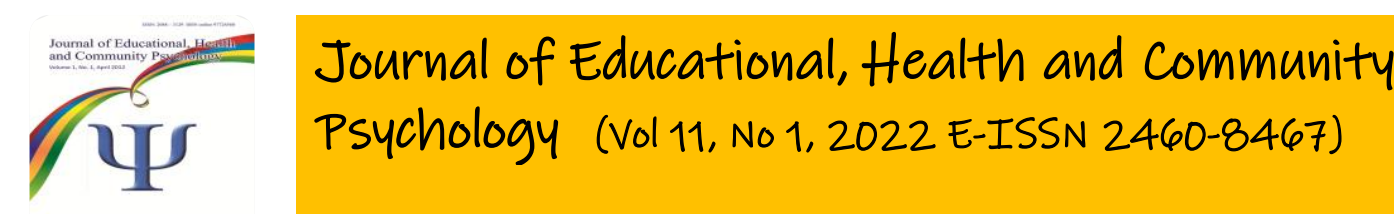

and anxiety about losing connections/relationships, experience different levels of decline. The anxiety aspect of losing access to communication experienced the highest decrease compared to other aspects.

In addition to quantitative data on nomophobia, there are several other findings based on the results of interviews conducted before and after the therapy process and evaluations in each therapy session. Researchers found several factors that caused the subject to experience anxiety when far away from the smartphone.

\section{Unpleasant past experiences}

Some subjects do not want past events to be repeated, as experienced by NL subjects who had an unpleasant incident when they were out of the house and did not bring their smartphone. YM's subjects also had conflicts with their parents because they did not immediately reply to messages.

\section{Parenting patterns and environmental demands}

Some subjects are anxious when away from their smartphone, as experienced by YM, whose parents are required to always reply to messages when not at home. SY subjects experience environmental demands such as lectures assignments that make him/her always carry their smartphone.

\section{Loneliness}

As stated by IT and DN subjects, some subjects feel lonely that they need a smartphone when they are alone. A smartphone is often used to overcome loneliness because it can provide entertainment and social.

\section{Needs The work of}

AG and DN subjects have the obligation and responsibility to update their work continuously. They still feel anxious even when they should be used to rest or gather with family. 


\section{Discussion}

Based on the results of data analysis, it can be concluded that there were differences in nomophobia scores between the control and experimental groups after receiving expressive writing therapy. The decrease of nomophobia scores in the experimental group shows that the subject's level of anxiety on smartphones has decreased. In line with the results of previous studies, which showed that expressive writing therapy could reduce various forms of anxiety, such as research by (Hartini et al. 2021), expressive writing therapy effectively reduces public speaking anxiety on the bully-victims students. Salmiyati \& Ervika (2020), in their research, also found that expressive writing therapy can be a cathartic method.

When away from the smartphone, they feel anxiety, worry, confusion, and fear of missing out on information. That result is in line with the results of quantitative data on the decrease in scores of nomophobia after being given expressive writing therapy. The most significant decrease in score for each aspect from the highest to the lowest was not being able to access information, giving up on comfort, being unable to communicate, and losing connection.

This study found several factors causing nomophobia, such as parenting. According to Savitri \& Winingsih (2020), one of the factors that influence someone to experience nomophobia is the freedom to access anything on a smartphone without any control from themselves or others, especially parents who free their children to access their smartphones always to provide news to parents when they are not at home. Loneliness also is one of the factors causing the subject's nomophobia. That is in line with the research results, which states that excessive use of smartphones is often used to overcome loneliness. Smartphones can quickly provide entertainment and social contacts (Saripah \&Pratiwi 2020). Other studies suggest that there is a significant relationship between nomophobia and loneliness. Therefore, people with nomophobia will feel lonely when they lose access to communication (Ciptadi \& Selviana 2020). The last is the demands of work that make the subject feel anxious when away from the smartphone, even at the time that should be used for rest or gathering with family or friends. This causes the subject to feel anxious when there are disturbances such as the absence of a quota wifi because the subject is required to fulfill work and always access smartphones at all times (Khoiryasdien \& Ardina, 2020) 


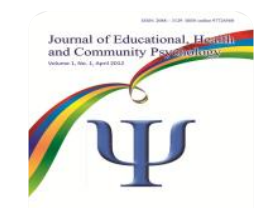

After the intervention, the subject felt relieved and could feel emotions. Several subjects such as YM, NL, AZ were writing down some past events that were not pleasant. Subjects are also more aware of the intensity of smartphone use and can be used as an evaluation and a reminder for the subject because it has brought various negative impacts so far. An example of a behavior that is realized is that the subject has been feeling uneasy when not holding a smartphone, driven to always check notifications even at inappropriate times, for example, when he is in college or when he should be resting. Some subjects feel anxious and unable to fight the urge to always carry a smartphone, even in situations where the subject should not need a smartphone.

Identification of problems in one of the stages of expressive writing therapy becomes an evaluation material and a reminder for the subject to improve or plan new behaviors that will gradually reduce the subject's anxiety. This result is in line with Sari and Sumirta's (2019) study on people Inside HIVIAIDS (PLWHA), which states that expressive writing therapy effectively reduces anxiety and can release emotional burdens such as worries, anxiety, and express thoughts and problems. Safaruddin, Murdiana, and Ridfah (2020) also stated that expressive writing helps individuals understand themselves to relieve stress, anxiety, addiction problems, fear of illness, loss, and life changes. Therapeutic models that include cathartic activities such as expressive writing can change the regulatory system or individual personality.

The change experienced by the subject begins with the emergence of an awareness of the condition of the self, which is expressed in writing. The following are some of the new insights gained by the subject that encourage the emergence of new behaviors:

Routine on a smartphone that turns out to be boring

This new understanding was obtained in session 2, namely the stage examination/writing exercise, which explores reactions to certain situations. An example can be seen based on the subject's expression: 


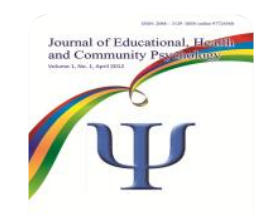

"...once one day I did not know what else to do, but I was also bored playing smartphones, scrolling Instagram, WhatsApp, and watching friends' stories. Sometimes it is entertaining, but I think it is a waste of time because I am lazy to do activities" (Subject SW).

Want to improve disturbed sleep hours.

This understanding was obtained in session 2, namely the stage examination/writing exercise, which explores reactions to certain situations. An example can be seen based on the subject's expression:

"... the fun of opening social media, my sleep hours are reduced. The food really wants to turn back my sleeping hours" (SW Subject)

There are many other fun activities without a smartphone.

This understanding is obtained in session 3, namely the stage juxtaposition/feedback, which aims to open new minds and attitudes to solve problems. As the subject said:

"...if I do not want to worry, I usually start cooking or reading. I also like watching videos related to self-development and writing them down" (Subject KH)

"... I played with my younger siblings, so over time, I did not think about holding a smartphone. Then I also do tasks that I have not done yet, such as organizational/college assignments, instead of worrying when I do not have my cell phone, I had better switch it to do my assignments" (SY Subject)

Often gets reprimands from others.

This understanding is obtained in session 3, namely the stage juxtaposition/feedback, which aims to open new thoughts and attitudes to solve the problems that are being experienced. As the subject said:

"...I swear I often get angry and get punished by my father because I often play HP. My life pattern became ugly, and I was allowed to play with my cell phone with my father only until I I pm after that the cellphones were collected to my father" (Subject AZ)

"I often get angry with my parents if I keep playing smartphones and rarely help my parents" (UL Subject) 


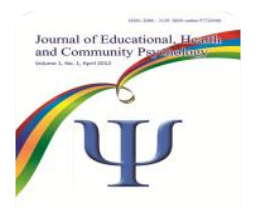

I was channeling a hobby that has often been forgotten.

This understanding was obtained in session 3, namely the stage juxtaposition/feedback, which aims to open new thoughts and attitudes to solve the problems that are currently being experienced. As the subject said:

"I distract myself when I cannot hold my cellphone by taking care of cats because I have many cats, I have to clean the dirt and make the food" (UL Subject)

Some of these new understandings encourage the subject to improve or learn new behaviors outlined in writing expressive session four, namely Application to the self. Writing emotional events will bring new understanding, and problem-solving can be poured through writing, which will serve as a reminder to solve a problem. This happens because there will be a thought process in the writing process that makes a person able to convey ideas to solve the problem logically (Niman, Septiningsih, and Tania 2019). These conditions can encourage the emergence of new understanding to overcome a problem. Gradually the subject applied the targets that had been written in session three and session 4. This could contribute to the decrease in the average score of nomophobia subjects during the measurement posttest and decrease again at the time of the measurement follow-up.

The process of expressive writing can also bring up memories, feelings, and hidden thoughts and organize new ideas and images related to individuals' new understandings. Expressive writing is holistic (overall) which is done consciously through a problem exploration process (Nurhasanah 2019). Based on the evaluation of each session, it can be concluded that the subject feels relieved can feel emotions about what is being written because some subjects wrote down events in the past that were not pleasant. This happens because of a cathartic process, namely releasing emotions by telling experiences in the form of words, sentences, or paragraphs (Pragholapati \& Yulianti 202I). In addition, expressive writing therapy can be used as a self-evaluation and reminder in using their smartphone. 


\section{Conclusion}

Based on the results of this study, it can be concluded that I) There was a change in scores nomophobia a significant between the control and experimental groups after being given expressive writing therapy; 2) The causes of nomophobia in the subject are factors of unpleasant past experiences, parenting and environmental demands that require the subject to always reply to messages, feel lonely, and work needs that require some subjects to constantly be updated in their work; 3) Subjects feel anxious, worried, confused, afraid of being left behind by information when they are far away from their smartphone before expressive writing therapy is carried out; 4) There is an effect of expressive writing on the management of feelings of anxiety when away from smartphones and some new understandings obtained by the subject after expressive writing therapy is carried out.

\section{Acknowledgment}

The authors would like to thank the Direktorat Jenderal Pendidikan Tinggi Kementerian Pendidikan, Kebudayaan, Riset, dan Teknologi for funding this research through the Program Kreativitas Mahasiswa (PKM) 2021.

\section{References}

Argumosa, V. .., G. .. Boada, and C. .. Vigil. (2017). An exploratory investigation of theoretical predictors of nomophobia using the mobile phone involvement questionnaire (NMIQ). Journal of Adolescents, 6, 127-35.

Ciptadi, A.W., \& Selviana. (2020). Relationship of extraversion and loneliness personality with tendency nomophobia in adolescents. Journal of IKRA-WITH Humanities 4, 78-86.

Darvishi, M., M. Noori, \& E. Karimi. (2019). Investigating different dimensions of nomophobia among medical students: a cross-sectional study. Journal of Medical Science, 5, 572-77.

Deursen, V., Bolle, J., Hegner, S. M., \& Kommers, P. A. (2015). Modeling habitual and addictive smartphone behavior: the role of smartphone usage types, emotional intelligence, social stress, self-regulation, age, and gender. Computers in Human Behavior, 4I I-20.

Fadhilah, L., Hayati, E. N., \& Bashori, K. (2020). Nomophobia among adolescents. Journal of Diversity, $7(1), 21-29$.

Fahrudin, H., \& Cahyaningtyas, Y.A. (2020). Duration of gadget use is related to teen social interaction at SMP Muhammadiyah 2 Karanganyar, Stethoscope, I (2). 97-105.

Gonzalez, L. Meija, P. Sancho, and Calvete. (2017). Adaptation of the nomophobia questionnaire 
(NMP-Q) to Spanish in a sample of adolescents. Actas Espanolas de Psiquiatrio, 2(3), I37-44.

Hartini, Sri, Willy, Fransisca, Selly Handayani, Gina Levina, and Ryan Andika Yusri. (202I). Efektivitas Terapi menulis ekspresif dalam menurunkan public speaking anxiety pada korban bullying. Psikoborneo Jurnal Ilmiah Psikologi, 9(2), 440-5I.

Khoiryasdien, D. A., \& Ardina.M. (2020) Qualitative descriptive study: The phenomenon of nomophobia student in Yogyakarta. URECOL: University Research Colloquium 285-89.

Lelepary, S. G., S. Mappeboki, S., \& Nurafriani. (2020). The relationship of behavior nomophobia with stress in students of SMA Negeri 21 Makassar. Scientific Journal of Health Diagnosis, 3(2) 189-93.

Li, J., A. Lepp, \& Barkley, J. E.. (20I5). Locus of control and cell phone use: implications for sleep quality, academic performance, and subjective well-being. Computers in Human Behavior, 2(3) 450-57.

Muyana, S., \& Widyastuti, A.D. (2017). Nomophobia (no-mobile phone phobia) adolescent diseases today. Prosiding Seminar Nasional Peran Bimbingan dan Konseling dalam Penguatan Pendidikan Karakter Universitas Ahmad Dahlan.

Niman, S., M. Septiningsih, \& C. Tania. (2019). The effect of expressive writing therapy on anxiety levels of bullying victims. Journal of Mental Nursing 7, I79-84.

Nurhasanah, N. (2019). The effect of expressive writing training on reducing stress levels in final year students of the faculty of psychology. Mercu Buana University, Yogyakarta.

Pragholapati, M. A. R., \& Yulianti, A.M. (202I). The effect of expressive writing therapy on depression levels in the elderly. Journal of Masters in Psychology at UMA I3, 55-64.

Ramaita, A., \& Vandelis. (2019). The relationship between addiction smartphone and anxiety (Nomophobia). Journal of Health 10, 89-93.

Rangka, B. I. (20I8). Measuring psychometric properties of the Indonesian version of the nomophobia questionnaire (NMP-Q): Insight from Rasch measurement tool. Journal of Physics, $4,1-7$.

Rohmadani, Z.V. (20I7). Relaksasi dan terapi menulis ekspresi sebagai penaganan kecemasan pada difabel daksa. Journal of Health Studies I, 18-27.

Safitri, A. E., \& Dewi, S. I. (2020). Expressive writing therapy to reduce students' academic stress levels in full-day schools. Journal of Guidance and Counseling, 5, 40-47.

Safaruddin, N.F., Murdiana, S., \& Ridfah, A. (2020). Expressive Writing Meningatkan Sel-Esteem Pecandu Narkoba di Program Rehabilitasi BNN Baddoka. Jurnal Intervensi Psikologi I, 27-36.

Salmiyati, S. W,, \& E. Ervika. (2020). Anxiety in children victims of bullying : Effectiveness of expressive writing therapy in reducing anxiety. Psychopolytan, 3(2), 49-56.

Sari, Ni M. D. K., \& I. Nengah Sumirta. (2019). Terapi menulis ekspresif terhadap tingkat kecemasan pada ODHA. Jurnal Gema Keperawatan, I2(I), 22-27. 

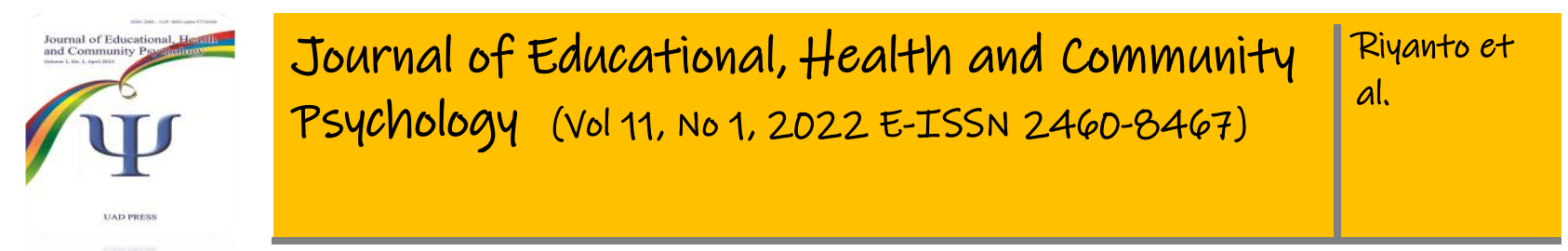

Saripah, N. A., \& L. Pratiwi. (2020). Relationship between loneliness and nomophobia in generation Z Students. Scientific Journal of Psychology and Research 6, 35-46.

Savitri, M.K., \& Winingsih, E. (202I). Kecenderungan nomophobia siswa SMAN 2 Ponorogo di masa pandemi covid 19. Jurnal BK Unesa, 12, 78-92.

Sudarji, S. (20I7). The relationship between nomophobia and self-confidence. Jurnal Psikologi Psibernetika, 10(I), 5I-6I.

Syahputra, Y., \& L. Erwinda. (2020). Differences in nomophobia students; Raasch analysis. JPPI (Journal of Indonesian Educational Research), 2(2), 69-76.

Yildirim, C. (2014). Exploring the dimension of nomophobia: Developing and validating a questionnaire using mixed method research (Thesis lowa State University, lowa) accessed from https://dr.lib.iastate.edu/server/api/core/bitstreams/fd0e2cee-d665-46d3-9036$04 \mathrm{fbfd} 973 \mathrm{e} 2 \mathrm{~d} /$ content. 